\title{
Resistance to hypertension mediated by intercalated cells of the collecting duct
}

\author{
Johannes Stegbauer, ${ }^{1,2}$ Daian Chen, ${ }^{2}$ Marcela Herrera, ${ }^{2}$ Matthew A. Sparks, ${ }^{2}$ Ting Yang, ${ }^{2}$ \\ Eva Königshausen, ${ }^{1}$ Susan B. Gurley, ${ }^{2}$ and Thomas M. Coffman ${ }^{2,3}$ \\ 'Division of Nephrology, Medical Faculty, University Hospital Düsseldorf, Düsseldorf, Germany. ${ }^{2}$ Division of Nephrology, \\ Department of Medicine, Duke University and Durham VA Medical Centers, Durham, North Carolina, USA. ${ }^{3}$ Cardiovascular \\ and Metabolic Disorders Program, Duke-NUS Medical School, Singapore.
}

\begin{abstract}
The renal collecting duct (CD), as the terminal segment of the nephron, is responsible for the final adjustments to the amount of sodium excreted in urine. While angiotensin II modulates reabsorptive functions of the $C D$, the contribution of these actions to physiological homeostasis is not clear. To examine this question, we generated mice with cell-specific deletion of $A T_{1 A}$ receptors from the CD. Elimination of $A T_{1 A}$ receptors from both principal and intercalated cells (CDKO mice) had no effect on blood pressures at baseline or during successive feeding of low- or high-salt diets. In contrast, the severity of hypertension caused by chronic infusion of angiotensin II was paradoxically exaggerated in CDKO mice compared with controls. In wild-type mice, angiotensin II induced robust expression of cyclooxygenase-2 (COX-2) in renal medulla, primarily localized to intercalated cells. Upregulation of COX-2 was diminished in CDKO mice, resulting in reduced generation of vasodilator prostanoids. This impaired expression of COX-2 has physiological consequences, since administration of a specific COX-2 inhibitor to CDKO and control mice during angiotensin II infusion equalized their blood pressures. Stimulation of COX-2 was also triggered by exposure of isolated preparations of medullary CDs to angiotensin II. Deletion of $A T_{1 A}$ receptors from principal cells alone did not affect angiotensin II-dependent COX2 stimulation, implicating intercalated cells as the main source of COX2 in this setting. These findings suggest a novel paracrine role for the intercalated cell to attenuate the severity of hypertension. Strategies for preserving or augmenting this pathway may have value for improving the management of hypertension.
\end{abstract}

Submitted: January 9, 2017 Accepted: February 14, 2017 Published: April 6, 2017

\section{Reference information:} JCI Insight. 2017;2(7):e92720. https:// doi.org/10.1172/jci.insight. 92720

\section{Introduction}

Precise control of urinary sodium excretion is a critical component of blood pressure regulation. At the molecular level, pathways regulating sodium handling by the kidney affect the reabsorptive functions of renal epithelia by modulating abundance and/or activities of specific channels and transporters. However, there is substantial heterogeneity in properties of solute and water reabsorption along the nephron. Accordingly, the final concentration of sodium in urine is determined by the aggregate actions of several diverse compartments of tubular epithelial cells. Among the different nephron segments, the collecting duct (CD) has been suggested to play a preeminent role in regulation of blood pressure. Based on its position in the terminal portion of the nephron, the $\mathrm{CD}$ is responsible for fine-tuning the final $\approx 5 \%$ of overall renal sodium reabsorption. Since $25,000 \mathrm{mEq}$ of sodium is filtered across the glomerulus each day, even small adjustments in the amount of sodium reclaimed by the $\mathrm{CD}$ can have a substantial impact on extracellular fluid volumes and, hence, on blood pressure. This is clearly illustrated by the severe hypertension seen in inherited disorders, such as Liddle's syndrome, caused by mutations affecting sodium reabsorption in the CD (1).

There are two main epithelial cell lineages in the CD: principal cells (PCs) and intercalated cells (ICs) (2). PCs are the most abundant and are responsible for the major portion of salt and water transport. While a key function of ICs is regulation of urinary acidification (3), more recent studies have shown that they also contribute to sodium and chloride flux $(4,5)$. Reabsorptive functions of CD epithelia are controlled by paracrine mediators including endothelin, aldosterone, and angiotensin II (6). Among these mediators, the influence of aldosterone on CD physiology and its impact on blood pressure have been most thoroughly characterized (7). On the other hand, the contribution of direct, aldosterone-independent effects of angiotensin II in the CD to blood pressure control has been difficult to establish. 
The predominant actions of angiotensin II to influence blood pressure are mediated by the type 1 angiotensin ( $\mathrm{AT}_{1}$ ) receptor (8), a member of the large family of $\mathrm{G}$ protein-coupled receptors (GPCRs). $\mathrm{AT}_{1}$ receptors are also the target of angiotensin receptor blockers (ARBs), effective and widely used antihypertensive agents (9). Recent studies from our laboratory have highlighted the crucial role of $\mathrm{AT}_{1}$ receptors within the kidney to control blood pressure (10) and promote the pathogenesis of hypertension (11). While $\mathrm{AT}_{1}$ receptors are expressed throughout the kidney in epithelial cells along the entire nephron (12), the specific cell lineages that are key targets for regulation of blood pressure by angiotensin II are not clear.

The purpose of the present studies was to define the physiological role of angiotensin II acting via $\mathrm{AT}_{1}$ receptors in the CD. There is significant expression of $\mathrm{AT}_{1}$ receptors in both PCs and ICs (13). Furthermore, studies in mice, cell culture, and isolated perfused tubules have shown that activation of $\mathrm{AT}_{1}$ receptors on PCs in the CD promotes sodium reabsorption by enhancing expression of the epithelial sodium channel $(\mathrm{ENaC})$ and its trafficking to the apical membrane and thereby contribute to the initiation of angiotensin II-dependent hypertension (14-16). In intercalated cells, $\mathrm{AT}_{1}$ receptors also modulate chloride and bicarbonate transport (17-19). Accordingly, our original hypothesis was that $\mathrm{AT}_{1}$ receptors in the CD would promote sodium reabsorption and thus would have prohypertensive actions. Yet in the course of our studies, we identified a dominant pathway linked to $\mathrm{AT}_{1}$ receptors in epithelial cells of the $\mathrm{CD}$ triggering expression of cyclooxygenase-2 (COX-2), generating vasodilator prostaglandins with powerful actions to attenuate the severity of hypertension.

\section{Results}

Elimination of $A T_{1 A}$ receptors from the $C D$ does not affect baseline blood pressure or salt sensitivity. In order to understand the impact of direct effects of angiotensin II in the CD on blood pressure regulation, we generated mice lacking the $\mathrm{AT}_{1 \mathrm{~A}}$ receptor in all epithelial cells of $\mathrm{CD}$ using cell-specific gene targeting. To this end, inbred 129/SvEv mice with a conditional (floxed) Agtrla allele were crossed with an inbred 129/ SvEv Hoxb7-Cre transgenic mouse line expressing Cre in both PCs and ICs of the CD (CDKO mice) as described previously (20). In order to verify tissue specificity of Hoxb7 promoter expression in the kidney, Hoxb7-Cre mice were crossed with a double-fluorescence reporter mouse $(m T / m G)$ (Figure 1A), where GFP expression is triggered by Cre recombinase. As shown in Figure 1, B and C, GFP expression is confined to epithelial cells of the CD with circumferential GFP expression in tubules. GFP fluorescence colocalized with AQP2, a marker for principal cells, and V-ATPase, a marker of intercalated cells, consistent with expression in both PCs and ICs (Figure 1, B and D). After verifying the specificity of Cre expression in CD in the Hoxb7-Cre mice, we assessed the extent of deletion of $\mathrm{AT}_{1 \mathrm{~A}}$ receptors from isolated medullary CDs (ICMDs). $\mathrm{AT}_{1 \mathrm{~A}}$ mRNA expression levels were significantly reduced, by $\approx 75 \%$, in ICMDs of CDKO mice compared with controls $(P<0.01)$ (Figure 1D).

To test the impact of $\mathrm{AT}_{1 \mathrm{~A}}$ receptors in the $\mathrm{CD}$ on blood pressure regulation, we measured blood pressures of 129/SvEv-Hoxb7-CreAgtr1a ${ }^{\text {flfl }}$ (CDKO) and their Cre-negative littermates (control) by radiotelemetry. As shown in Figure 1E, baseline mean arterial blood pressures (MAPs) on a normal-salt $(0.4 \%$ $\mathrm{NaCl})$ diet were very similar between control and CDKO mice $(119 \pm 1 \mathrm{mmHg}$ vs. $121 \pm 2 \mathrm{mmHg} ; n=10)$. To determine whether deletion of $\mathrm{AT}_{1 \mathrm{~A}}$ receptors from $\mathrm{CD}$ would affect adaptation to changes in dietary salt intake, blood pressures were continuously measured while CDKO and control mice were fed normal, low- $(<0.002 \% \mathrm{NaCl})$, and high-salt $(6 \% \mathrm{NaCl})$ diets for 5 consecutive days each. Upon the transition from normal to low-salt diet, blood pressure decreased significantly in controls (119 \pm 1 to $115 \pm 1 \mathrm{mmHg} ; P$ $<0.02 ; n=10)$ and then increased to $131 \pm 5 \mathrm{~mm} \mathrm{Hg}(P<0.01 ; n=10)$ after 5 days on the high-salt diet, consistent with sodium sensitivity typically seen in 129 strain mice (21). As shown in Figure 1E, the magnitude and pattern of blood pressure changes were virtually identical in CDKO mice. Thus, these results suggest that $\mathrm{AT}_{1 \mathrm{~A}}$ receptors in the $\mathrm{CD}$ do not have a major impact on baseline blood pressure or responses to extremes of dietary sodium intake.

Deletion of $A T_{1 A}$ receptors from the $C D$ exaggerates angiotensin $I I$-dependent hypertension. To determine whether $\mathrm{AT}_{1 \mathrm{~A}}$ receptors in the $\mathrm{CD}$ contribute to the pathogenesis of hypertension, we induced hypertension in CDKO and control mice by infusing angiotensin II by mini-osmotic pump at 1,000 ng/ $\mathrm{kg} / \mathrm{min}$ for 2 weeks. As shown in Figure 2A and Supplemental Figure 1 (supplemental material available online with this article; https://doi.org/10.1172/jci.insight.92720DS1), angiotensin II infusion increased blood pressures abruptly and significantly in control mice, and increases in MAPs and systolic pressures were sustained throughout the period of angiotensin II infusion. MAP in CDKO mice averaged over 14 days of angiotensin II infusion 

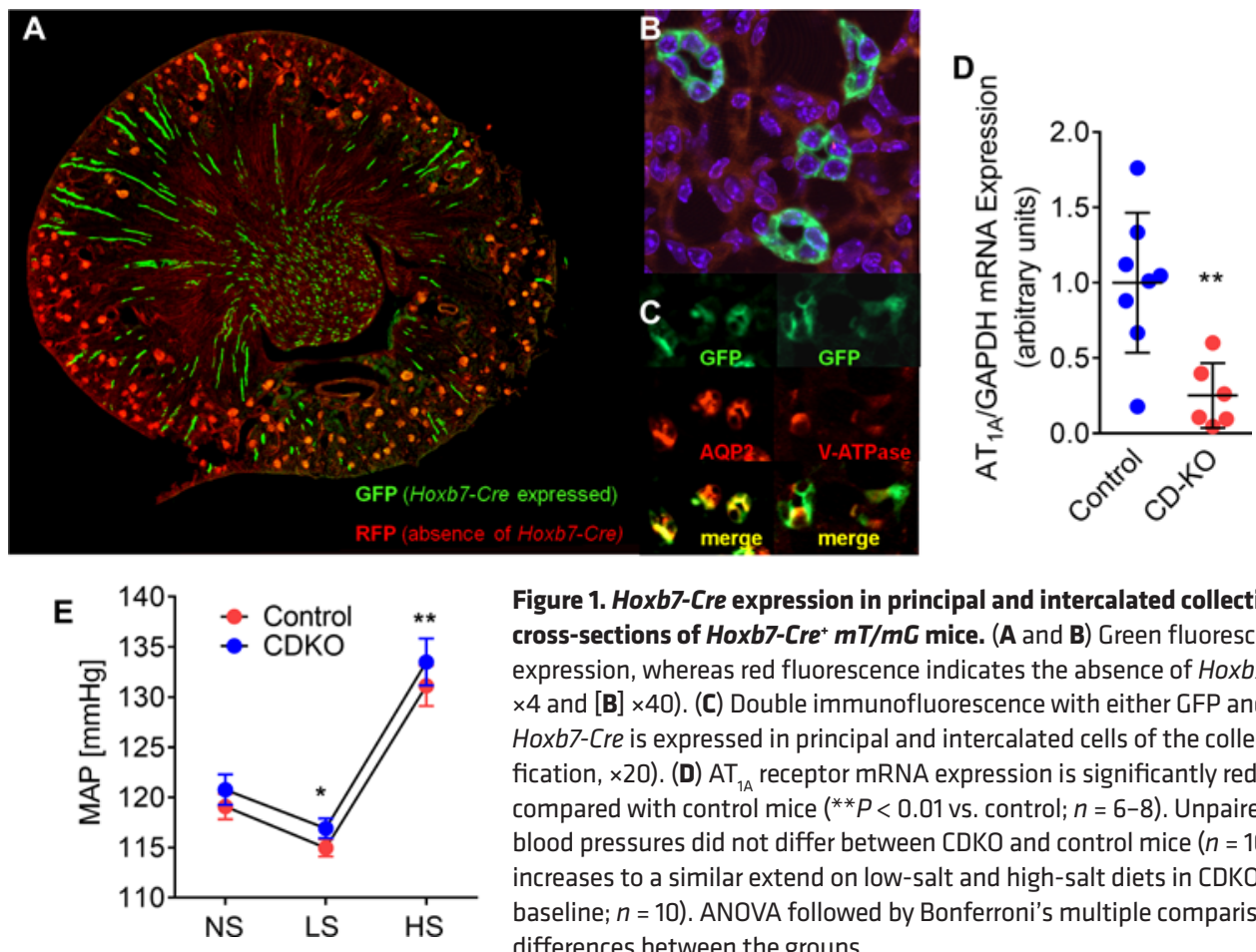

Figure 1. Hoxb7-Cre expression in principal and intercalated collecting duct cells. Representative kidney cross-sections of Hoxb7-Cre+ $\mathbf{m T} / \mathbf{m G}$ mice. (A and B) Green fluorescence indicates the presence of Hoxb7-Cre expression, whereas red fluorescence indicates the absence of Hoxb7-Cre expression (original magnification, [A] $\times 4$ and [B] $\times 40$ ). (C) Double immunofluorescence with either GFP and AQP2 or GFP and V-ATPase confirms that Hoxb7-Cre is expressed in principal and intercalated cells of the collecting duct in the kidney (original magnification, $\times 20$ ). (D) $A T_{1 A}$ receptor mRNA expression is significantly reduced in isolated collecting ducts of CDKO compared with control mice ( ${ }^{* *} P<0.01$ vs. control; $n=6-8$ ). Unpaired Student's $t$ test was used. (E) Baseline blood pressures did not differ between CDKO and control mice $(n=10)$. Blood pressures significantly decrease and increases to a similar extend on low-salt and high-salt diets in CDKO and control mice $\left({ }^{*} P<0.05 ;{ }^{*} P<0.01\right.$ vs. baseline; $n=10$ ). ANOVA followed by Bonferroni's multiple comparisons post-hoc test was used to compare the differences between the groups.

was $163 \pm 3 \mathrm{mmHg}$, compared with $151 \pm 3 \mathrm{mmHg}$ in controls $(P<0.01 ; n=16)$. To determine whether this exaggerated hypertensive response to angiotensin II in CDKO mice was accompanied by changes in renal sodium handling, we measured urinary sodium excretion during the first 7 days of the angiotensin II infusion, while sodium intake was clamped at a constant level. As shown in Figure 2B, we found that the extent of the cumulative positive sodium balance was significantly increased in CDKO mice compared with controls during the first 5 days of angiotensin II infusion $\left(0.75 \pm 0.07\right.$ vs. $0.50 \pm 0.04 \mathrm{mmol} ;{ }^{*} P<0.02 ; n=$ 6). Thus, elimination of $\mathrm{AT}_{1 \mathrm{~A}}$ receptors from PCs and ICs of the $\mathrm{CD}$ augmented hypertension in $\mathrm{CDKO}$ mice, and this was associated with reduced natriuresis, indicating enhanced renal sodium reabsorption and alteration in the pressure-natriuresis response.

The enhanced hypertensive response in CDKO mice is not due to impaired NO or aldosterone generation. Our observation that $\mathrm{CDKO}$ mice have an exaggerated response to chronic infusion of angiotensin II suggests that $\mathrm{AT}_{1}$ receptors in epithelia of the $\mathrm{CD}$ trigger a pathway with powerful effects to oppose the development of hypertension, such that in their absence, the severity of hypertension is enhanced. Previous studies indicate that NO derived from renal medullary epithelial cells may modulate the development of hypertension $(22,23)$. Thus, we considered the possibility that $\mathrm{AT}_{1 \mathrm{~A}}$ receptors within the $\mathrm{CD}$ might stimulate $\mathrm{NO}$ generation as a compensatory response, and elimination of this pathway might be responsible for the severe hypertension we observed in CDKO mice. To test this possibility, we first measured urinary nitrate/nitrite excretion as a measure of renal NO production in control and CDKO mice before and during angiotensin II infusion. As shown in Figure 3A, equivalent levels of urinary nitrate/nitrite were seen at baseline. During the first 5 days of angiotensin II infusion, urinary NO nitrate/nitrite levels tended to be higher in CDKO mice, but this difference did not achieve statistical significance.

To further test the role of $\mathrm{NO}$ in this response, control and CDKO mice were infused with angiotensin II as above while their blood pressures were monitored by radiotelemetry. After 1 week of angiotensin II infusion (Figure 3B and Supplemental Figure 2), MAPs and systolic arterial blood pressures in CDKO mice was significantly higher than in controls $(183 \pm 3 \mathrm{mmHg}$ vs. $169 \pm 4 \mathrm{mmHg} ; P<0.05 ; n=6)$, as we had seen previously. At this point, $N^{\mathrm{G}}$-nitro-L-arginine methyl ester (L-NAME; $20 \mathrm{mg} / \mathrm{kg} / \mathrm{d}$ ) was added to their drinking water to inhibit NO generation. As depicted in Figure 3B, administration of L-NAME caused blood pressures to significantly rise further in both groups. After 1 week of L-NAME plus angiotensin II, the absolute difference in blood pressure between the controls and CDKO mice was further enhanced, suggesting that impaired NO generation was not the cause of exaggerated hypertension in the CDKO mice. 
A

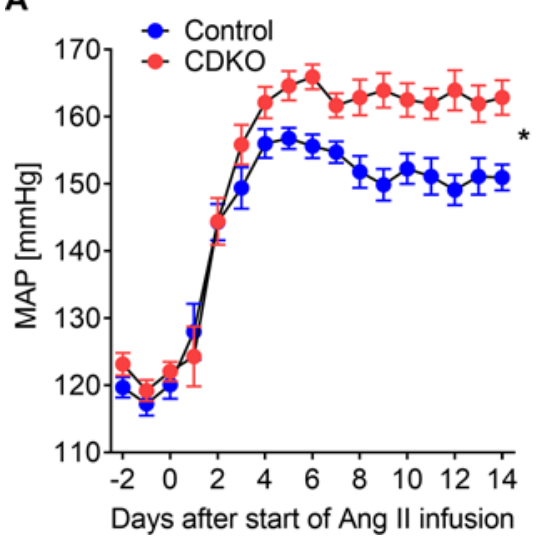

B

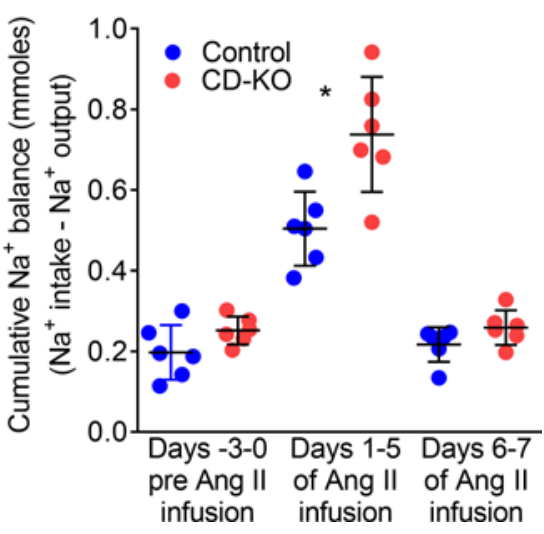

Figure 2. Exaggerated blood pressure response to angiotensin II in mice lacking AT1 receptors from the collecting duct (CDKO mice). (A) Chronic angiotensin II infusion (1,000 $\mathrm{ng} / \mathrm{kg} / \mathrm{min}$ ) caused a greater hypertensive blood pressure response in CDKO compared with control mice (MAP: $163 \pm 3$ vs. $151 \pm 3 \mathrm{mmHg}$, ${ }^{*} P<0.001 \mathrm{vs}$. angiotensin II control; $n=16$ ). (B) In accordance with the exaggerated blood pressure response, cumulative positive sodium balance was significantly increased in CDKO compared with control mice during the first 5 days of angiotensin II infusion $(0.75 \pm 0.07 \mathrm{vs}$. 0.50 $\pm 0.04 \mathrm{mmol} ;{ }^{*} P<0.02$ vs. angiotensin II control; $n=6$ ). ANOVA followed by Bonferroni's multiple comparison post-hoc test was used to compare the differences between the groups.

As aldosterone also may contribute to the pathogenesis of angiotensin II-dependent hypertension, we also compared aldosterone responses in $\mathrm{CDKO}$ and control mice. Accordingly, we measured urinary aldosterone excretion rates, which were similar in angiotensin II-infused CDKO and control mice $(14,556 \pm 1,571$ vs. $12,306 \pm 1,428$ pg/24-hour urine; $P=0.30, n=12$ ).

$A T_{1 A}$ receptors in the $C D$ trigger expression of $C O X-2$. In exploring other possible mechanisms to explain the more severe hypertension seen in CDKO mice, we considered previous studies suggesting that COX-2 in the kidney may modify effects of angiotensin II upon blood pressure (24). Accordingly, we measured expression of COX-2 in kidneys from CDKO and control mice at baseline and after 2 weeks of chronic angiotensin II infusion. In the renal medulla, COX-2 mRNA levels were similar in control and CDKO mice at baseline (Fig-

ure 4A). With angiotensin II infusion, levels of COX-2 mRNA increased almost 10-fold in controls. However, as shown in Figure 4A, while COX-2 expression was also enhanced by angiotensin II in the CDKO mice, COX-2 levels were attenuated by $\approx 50 \%$ compared with controls $(10.7 \pm 1.8$ vs. $5.5 \pm 0.5$ arbitrary units; $P<0.01 ; n=11)$. Similarly, inner medullary COX-2 protein levels in CDKO mice were diminished after chronic angiotensin II infusion compared with controls as shown in Figure 4B. On the other hand, in renal cortex, levels of COX-2 mRNA were similar in controls and CDKO mice at baseline and with angiotensin II infusion (data not shown).

To determine the cellular source of angiotensin II-stimulated COX-2 expression, we examined medullas from kidneys of wild-type mice by immunocytochemistry and confocal microscopy. At baseline, we found minimal COX-2 staining in renal medullae of untreated wild-type mice (Figure 4C, top row). By contrast, as shown in the bottom row of Figure $4 \mathrm{C}$, distinct cellular expression of COX-2 was readily apparent after chronic infusion of angiotensin II. COX-2 staining colocalized almost exclusively with V-ATPase, a marker for ICs, indicating that angiotensin II causes potent upregulation of COX-2 in ICs in the renal medulla (bottom row). Moreover, aquaporin 2 (AQP2), a specific marker for PCs, did not colocalize with COX-2 (Supplemental Figure 3) suggesting that the upregulation of COX-2 occurs in ICs and not PCs of the CD.

A

Figure 3. NO does not modify the exaggerated blood pressure response to angiotensin II in mice lacking AT, receptors from the collecting duct (CDKO mice). (A) During the first 5 days of angiotensin II infusion, cumulative urinary nitrate/nitrite levels did not differ significantly between CDKO and control mice (102.7 \pm 26.30 vs. $69.34 \pm 27.68 \mathrm{mM} / \mathrm{mg} / \mathrm{dl}$ creatinine; $P=$ $0.12 ; n=6$ ). Unpaired Student's $t$ test was used to compare the various groups. (B) The exaggerated blood pressure response to angiotensin II is not due to impaired NO generation, as chronic administration of L-NAME $(20 \mathrm{mg} / \mathrm{kg} / \mathrm{d})$ did not decrease the blood pressure difference between CDKO and control mice $(n=6)$. ANOVA followed by Bonferroni's multiple comparison post-hoc test was used to compare the differences between the groups.

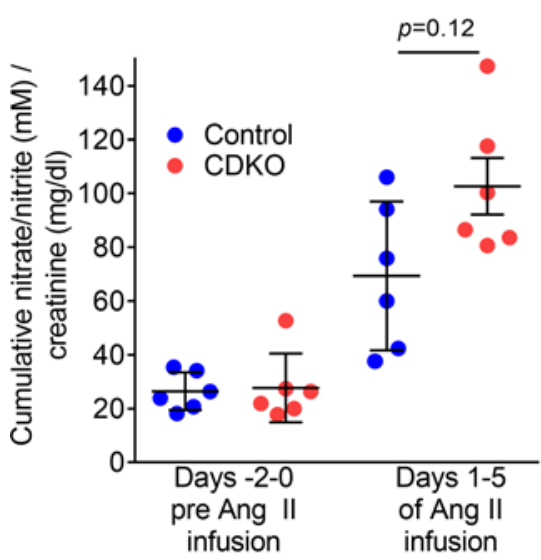

B

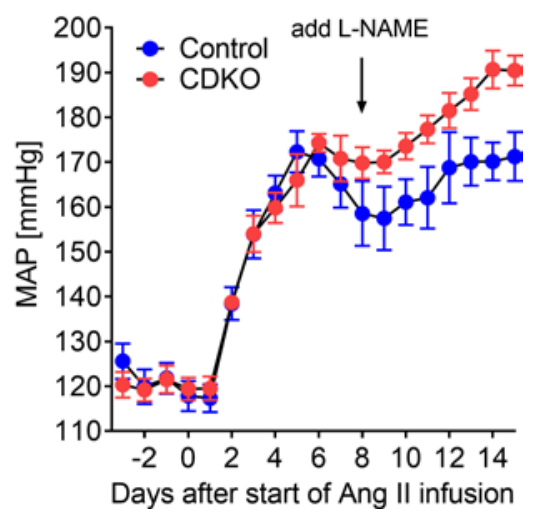



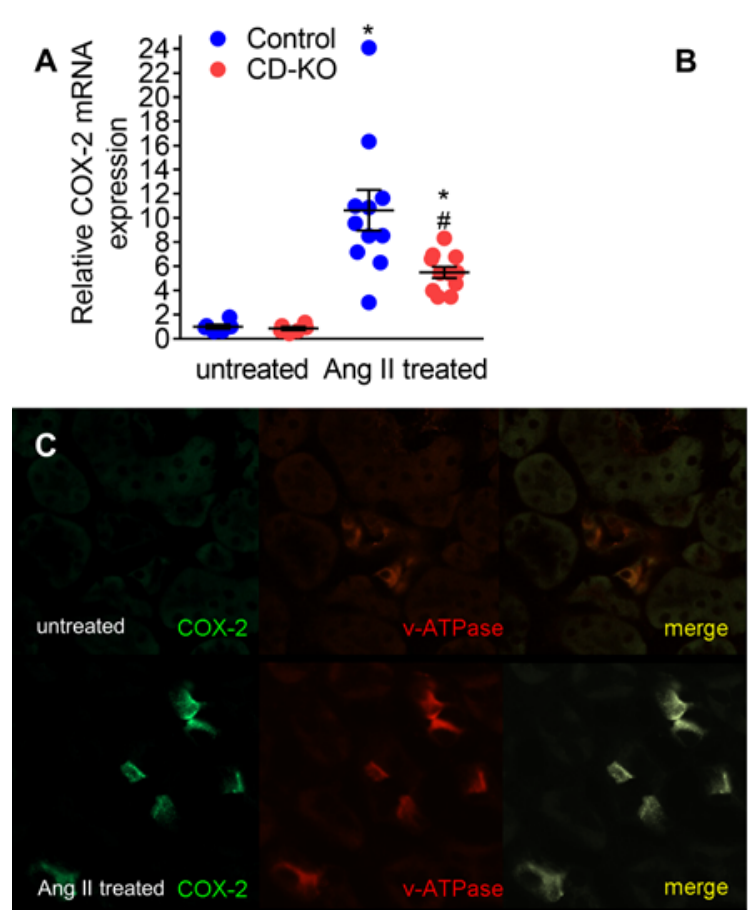

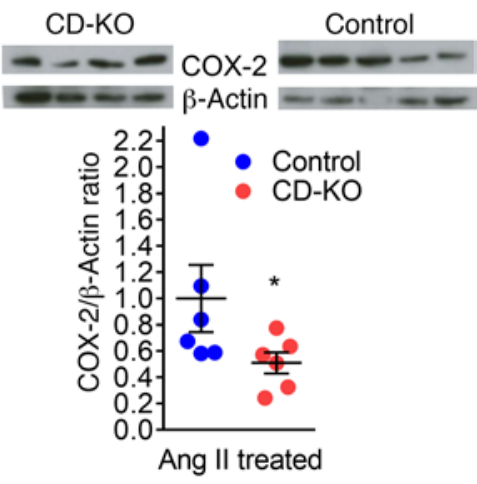

Ang II treated

Figure 4. Deletion of collecting duct-specific $\mathbf{A T}_{1 \mathbf{A}}$ receptors modifies medullary CoX-2 expression. (A) After 14 days of angiotensin infusion, medullary COX-2 mRNA expression was significantly increased in CDKO (1.0 $\pm 0.1 \mathrm{vs}$. $\left.5.5 \pm 0.5 \mathrm{AU} ;{ }^{*} P<0.001 ; n=6-11\right)$ and control mice (1.0 \pm 0.2 vs. $\left.10.7 \pm 1.8 \mathrm{AU} ;{ }^{*} P<0.001 ; n=6-11\right)$ compared with untreated mice. Moreover, the increase in medullary COX-2 mRNA expression was significantly attenuated in CDKO compared with control mice (10.7 \pm 1.8 vs. $\left.5.5 \pm 0.5 \mathrm{AU} ;{ }^{\#} P<0.01 ; n=11\right)$. Unpaired Student's $t$ test was used to compare the various groups. (B) Likewise, medullary COX-2 protein levels were significantly reduced in angiotensin II- treated CDKO compared with control mice ( $0.5 \pm 0.1$ vs. $\left.1.0 \pm 0.3 ;{ }^{*} P<0.05 ; n=6\right)$. Unpaired Student's $t$ test was used. Lanes were run on the same gel but were noncontiguous. See complete unedited blots in the supplemental material. Results are representative of 3 independent experiments. (C) In order to determine the cellular source of COX-2, immunocytochemistry was performed in the medulla of untreated and angiotensin II-treated control mice. In untreated mice, representative confocal laser scanning microscopy showed minimal CoX-2 staining. By contrast, in angiotensin II-treated control mice, COX-2 staining was apparent and colocalized almost completely with V-ATPase, a marker for intercalated cells (original magnification, $\times 20$ ).

Angiotensin II stimulates COX-2 expression in isolated inner medullary CDs and MDCK cells. To verify the capacity of angiotensin II to regulate COX-2 expression in CD epithelia, we next carried out a series of studies in IMCDs in vitro. Suspensions enriched for CD segments were prepared as described previously $(25,26)$ with slight modifications. To test whether we could recapitulate the stimulation of COX-2 by angiotensin II that we observed in vivo, we incubated suspensions of IMCD with angiotensin II in vitro and quantitated COX-2 protein levels in protein homogenates by Western blot analysis using a specific anti-COX-2 antibody. As shown in Figure 5A, following incubation with angiotensin II, there was a concentration-dependent increase in COX-2 protein levels, with a maximal $>2$-fold increase at concentrations of $10^{-7} \mathrm{M}$ angiotensin II. By contrast, angiotensin II did not affect COX-2 levels in IMCDs isolated from Agtr1a $^{-/-}$mice lacking $\mathrm{AT}_{1 \mathrm{~A}}$ receptors (Figure 5B), confirming an absolute requirement for the $\mathrm{AT}_{1 \mathrm{~A}}$ receptor to mediate this response. Yet the response was completely preserved in mice lacking $\mathrm{AT}_{1 \mathrm{~A}}$ receptors only in PCs of the CD (AQP2-Cre Agtrla $\left.{ }^{f / f}\right)$, and significantly greater than in CDs from CDKO mice, as shown in Figure 5, C and D. These studies in IMCD suspensions indicate that angiotensin II directly stimulates COX-2 expression in ICs of the CD via activation of $\mathrm{AT}_{1 \mathrm{~A}}$ receptors. Finally, we also performed studies in Madin-Darby canine kidney clone 11 (MDCK C-11) cells, which resemble ICs of the CD (Supplemental Figure 4) (27). In MDCK C-11 cells permanently transfected with $\mathrm{AT}_{1}$ receptors, angiotensin increased COX-2 expression in a concentration-dependent manner (Figure $5 \mathrm{E}$ ). This increase was also accompanied by a significant increase in the generation of $\mathrm{PEG}_{2}$ (Figure $5 \mathrm{~F}$ ).

Stimulation of vasodilator prostanoids by angiotensin II is diminished in CDKO mice. To determine whether the observed difference in expression of COX-2 in the medullary $\mathrm{CD}$ impacts the generation of 

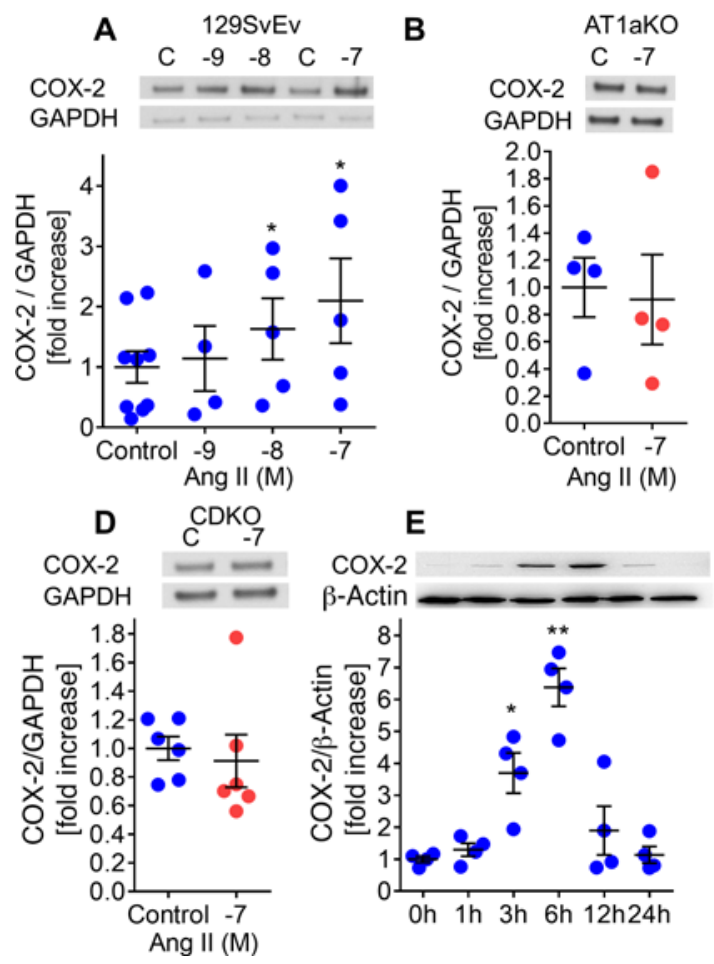
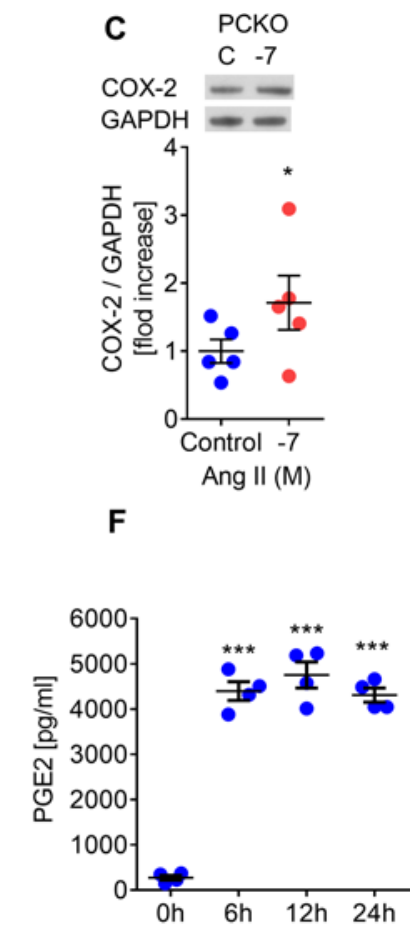

Figure 5. Densitometric analysis of COX-2 in isolated inner medullary collecting ducts of 129/ SvEv, Agtr1a $^{-/}$, PCKO, and CDKO mice. (A) Angiotensin II (Ang II) increases COX-2 expression in isolated collecting ducts of $129 / \mathrm{SvEv}$ control mice in a dose-dependent manner $\left(10^{-8} \mathrm{M}: 1.8 \pm 0.5 \mathrm{COX}-\right.$ $2 /$ GAPDH [fold increase], ${ }^{*} P<0.05$ vs. control; $n=5 ; 10^{-7} \mathrm{M}: 2.3 \pm 0.7$ COX-2/GAPDH [fold increase], $P<0.05$ vs. control; $n=5$ ). Paired Student's $t$ test was used to compare the different groups. (B) Angiotensin II (10-7 M) failed to increase COX-2 protein in isolated collecting ducts of Agtr1a ${ }^{-1-}$ mice. ( $($ and $\mathbf{D})$ Angiotensin II (10-7 $\mathrm{M}$ ) increases COX-2 protein levels by about 2-fold in isolated collecting ducts of mice lacking the $A_{1 A}$ receptor only in principal cells (1.7 \pm 0.2 vs. $1.0 \pm 0.4 ;{ }^{*} P<0.05 ; n=5$ ) but failed to induce COX-2 expression in CDKO mice. Unpaired Student's $t$ test was performed to compare the various groups. (E and $\mathbf{F})$ Angiotensin $I I\left(10^{-7} \mathrm{M}\right)$ significantly induced COX-2 expression in MDCK cells ( $1.00 \pm 0.10$ [0 hours]; $1.30 \pm 0.20$ [ 1 hour]; $3.70 \pm 0.63$ [3 hours]; $6.38 \pm 0.60$ [6 hours]; $1.90 \pm 0.76$ [12 hours]; $1.14 \pm 0.26$ [24 hours]; ${ }^{*} P<0.05$, ${ }^{* *} P<0.01 ; n=4$ ) and significantly increased prostaglandin $\mathrm{E}_{2}\left(\mathrm{PGE}_{2}\right)$ generation measured in the supernatant of the stimulated MDCK cells (272 \pm 53 [0 hours]; 4,397 \pm 288 [6 hours]; 4,752 \pm 209 [12 hours]; 4,310 \pm 157 [24 hours]; ${ }^{* *} P<0.001 ; n$ =4). ANOVA followed by Bonferroni's multiple comparison post-hoc test was used to compare the differences between the groups. See complete unedited blots in the supplemental material. prostanoids by the kidney, we measured urinary excretion of metabolites of key vasodilator prostanoids, $\mathrm{PGE}_{2}$ and prostacyclin, along with $\mathrm{TXB}_{2}$, the stable metabolite of the potent vasoconstrictor eicosanoid thromboxane $\mathrm{A}_{2}\left(\mathrm{TXA}_{2}\right)$. As shown in Figure 6, A-C, there were no differences between control and CDKO mice in urinary excretion of any of these prostanoids at baseline. Infusion of angiotensin II caused significant increases in urinary excretion of all 3 prostanoids in the control mice. Although urinary excretion of $\mathrm{TXB}_{2}$ increased to a similar extent in controls and CDKO mice $(3,233 \pm 839$ vs. 4,451 $\pm 1,011 \mathrm{pg} / 24$-hour urine with angiotensin II; $P=0.37 ; n=10-11$ ), there was a significant attenuation of angiotensin II-stimulated excretion of $\mathrm{PGE}_{2}(2,395 \pm 441$ vs. 5,852 \pm $1,726 \mathrm{pg} / 24$-hour urine; $P<0.01 ; n=10-11$ ) and 6-keto-PGF1a $(1,889 \pm 386$ vs. $5,125 \pm$ $1,374 \mathrm{pg} / 24$-hour urine; $P<0.05 ; n=10-11$ ) in CDKO mice compared with controls (Figure $6, \mathrm{~A}-\mathrm{C})$. Thus, in the $\mathrm{CDKO}$ mice, the failure to fully upregulate medullary COX-2 expression during angiotensin II infusion was associated with impaired generation of vasodilator prostanoids, resulting in a skewing of the ratio of vasodilator to vasoconstrictor prostanoids in the kidney.

COX-2 inhibition abolishes the difference in blood pressure between CDKO mice and controls during angiotensin II infusion. To test whether reduced expression of COX-2 and production of vasodilator prostanoids is responsible for the augmented blood pressure response in CDKO mice, we treated both groups with a specific COX-2 inhibitor (rofecoxib) during chronic angiotensin II infusion. As shown in

Figure 7 and Supplemental Figure 5, after 1 week of angiotensin II infusion, systolic blood pressure and MAP were significantly higher in CDKO mice $(156 \pm 4 \mathrm{mmHg})$ compared with controls $(142 \pm 6$ $\mathrm{mmHg} ; P<0.05 ; n=10)$, as noted previously. At that point, treatment with rofecoxib $(10 \mathrm{mg} / \mathrm{kg})$ was initiated, which caused blood pressures to increase significantly ( $P<0.05$ vs. pre-treatment) in both groups to $163 \pm 6 \mathrm{mmHg}$ in the CDKO mice and $161 \pm 5 \mathrm{mmHg}$ in controls to nearly identical levels. Thus, the COX-2 inhibitor completely abolished the blood pressure difference between the two groups.

\section{Discussion}

The major objective of these studies was to define the contribution of $\mathrm{AT}_{1 \mathrm{~A}}$ receptors in $\mathrm{CD}$ epithelium to blood pressure homeostasis. $\mathrm{AT}_{1}$ receptors are expressed throughout the distal nephron (12), and relatively high concentrations of angiotensin II can be detected in the distal tubular fluid (28). Previous studies from other laboratories have shown that $\mathrm{AT}_{1}$ receptors can modulate functions of epithelial cells in the CD. For example, on the apical membrane of the PCs in the cortical CD (CCD), luminal angiotensin II stimulates amiloride-sensitive sodium transport by increasing activity of the ENaC through an $\mathrm{AT}_{1}$ receptor-dependent mechanism influencing the initial phase of angiotensin II-dependent hypertension $(14,16,29)$. Angiotensin II also increases chloride absorption in the CCD through a 
A

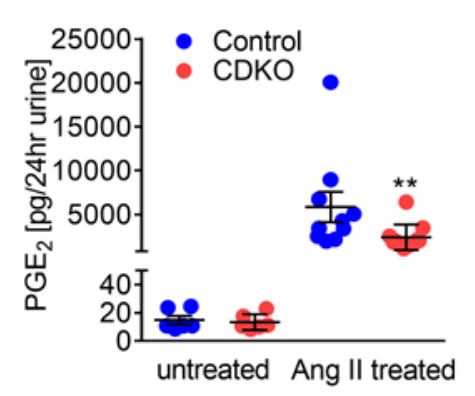

C

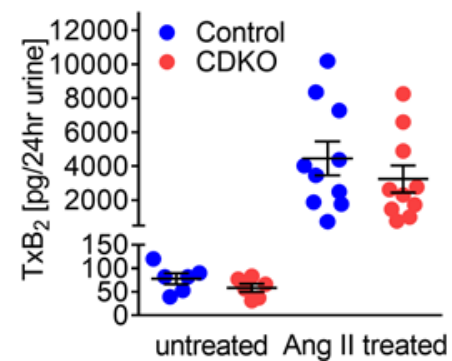

untreated Ang II treated
B

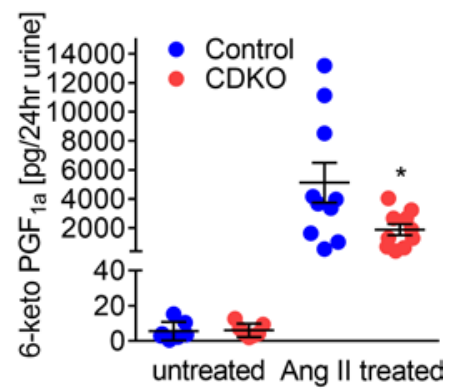

Figure 6. $\mathrm{AT}_{1 \mathrm{~A}}$ receptors in the collecting duct stimulate vasodilator prostanoids. After chronic angiotensin II infusion, urinary metabolites of the vasodilator prostanoids (A) $\mathrm{PGE}_{2}$ and (B) prostacyclin (6-keto $\mathrm{PGF}_{1 \mathrm{a}}$ ) were significantly reduced in CDKO mice compared with control mice $\left(\mathrm{PEG}_{2}: 2,395 \pm 441\right.$ vs. $5,852 \pm 1,726 \mathrm{pg} / 24$-hour urine; ${ }^{* *} P<0.01$ vs. angiotensin II-treated controls, $n=10-11$; prostacyclin 6-keto PGF 1 : 1,889 \pm 386 vs. 5,125 $\pm 1,374$ pg/24-hour urine; ${ }^{*} P<0.05$ vs. angiotensin II-treated controls, $\left.n=10-11\right)$. (C) In contrast, urinary thromboxane (TXB $)$ excretion did not differ between CDKO and control mice (3,233 \pm 839 vs. $4,451 \pm 1,011 \mathrm{pg} / 24$ hour urine, $n=10-11)$. Unpaired Student's $t$ test was performed to compare the different groups.

mechanism that requires pendrin (30). Furthermore, activation of $\mathrm{AT}_{1}$ receptors on the basolateral membrane of CCD cells stimulates the activity of potassium channels via an NO-dependent pathway (31).

Since the terminal portions of the nephron including the $\mathrm{CD}$ make the final adjustments in salt and water excretion ultimately determining the characteristics of urine flow and composition, we anticipated that direct, aldosterone-independent actions of $\mathrm{AT}_{1}$ receptors to modulate sodium handling at these sites would impact blood pressure homeostasis and modify susceptibility to hypertension. Instead, we find that eliminating $\mathrm{AT}_{1 \mathrm{~A}}$ receptors from $\mathrm{CD}$ has negligible effects on baseline blood pressure or homeostatic responses to large alterations in dietary sodium intake. This finding is consistent with our recently published work showing that specific deletion of $\mathrm{AT}_{1 \mathrm{~A}}$ receptors from PCs does not affect baseline blood pressure and is associated with a modest attenuation of angiotensin II-dependent hypertension (16). Compared with this apparently dispensable role of $\mathrm{AT}_{1}$ receptors in the $\mathrm{CD}$ at baseline, we found that elimination of $\mathrm{AT}_{1 \mathrm{~A}}$ receptors from the proximal tubule lowers baseline blood pressure and significantly impacts proximal sodium handling (21). Thus, within the renin-angiotensin system (RAS), there appears to be a division of control mechanisms between the proximal tubule and CD. Direct actions of $\mathrm{AT}_{1}$ receptors have profound effects in the proximal nephron, whereas aldosterone seems to have a dominant role in the CD. This compartmentalization of regulatory effects of angiotensin II and aldosterone between nephron segments likely provides an expanded capacity for more precise control of sodium and potassium homeostasis (32).

Although deletion of $\mathrm{AT}_{1 \mathrm{~A}}$ receptors from $\mathrm{CD}$ epithelium had no apparent effect on baseline blood pressure, this caused a marked and unexpected exaggeration in the severity of angiotensin II-dependent hypertension. We show here that worsening of hypertension caused by deletion of $\mathrm{AT}_{1 \mathrm{~A}}$ receptors from $\mathrm{CD}$ is due to a failure to upregulate COX-2 in ICs and consequent impaired generation of vasodilator prostanoids. The potent role of COX-2 to influence blood pressure regulation is highlighted by consistent clinical associations between administration of specific COX-2 inhibitors and development of hypertension (33). However, definition of the critical mechanisms of blood pressure control by COX-2 has been incomplete. In animal studies, COX-2-derived prostanoids promote sodium excretion (34). Moreover, the capacity for COX-2 in the renal medulla to modulate blood pressure is suggested by observations that COX-2 expression in the medulla is enhanced with high-salt feeding (35) and selective intramedullary infusion of COX-2 inhibitors induces hypertension in rats fed a high-salt diet (36). Similarly,

Figure 7. Effects of COX-2 inhibition on angiotensin II-dependent hypertension. After 1 week of chronic angiotensin II treatment, CDKO and control mice were co-treated with a specific COX-2 inhibitor (rofecoxib $10 \mathrm{mg} / \mathrm{kg} / \mathrm{d}$ ). After 1 week of angiotensin II infusion, MAP was significantly higher in CDKO compared with control mice (156 \pm 4 vs. $\left.142 \pm 6 \mathrm{mmHg} ;{ }^{*} P<0.05 ; n=10\right)$. Co-treatment with rofecoxib $(10 \mathrm{mg} / \mathrm{kg})$ caused a significant increase in blood pressure in both groups and abolished the difference in blood pressure between CDKO and control mice (163 \pm 6 vs. $161 \pm 5 \mathrm{mmHg} ; P=0.70 ; n=10$ ). ANOVA followed by Bonferroni's multiple comparisons post-hoc test was used to compare the differences between the groups.

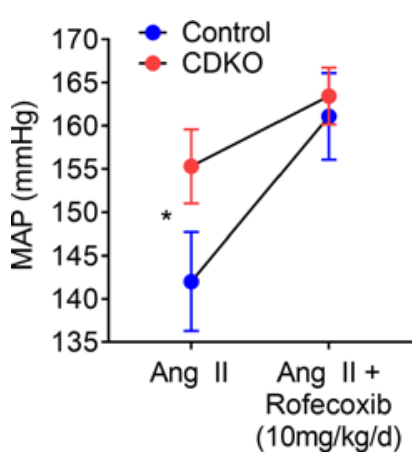


COX-2 inhibition selectively reduces medullary blood flow in mice and induces an exaggerated pressor response to angiotensin II (24). Such alterations in renal blood flow can affect blood pressure homeostasis, since changes in medullary blood flow significantly impact sodium excretion (37-39). On the other hand, prostanoids generated by COX-2 may also directly impact sodium and fluid reabsorption by renal epithelial cells (40). In addition, Zhang and colleagues recently showed that COX-2 activation in macrophages attenuates sodium sensitivity by enhancing natriuresis (41).

While a role for COX-2 in renal medulla to protect against hypertension has been suggested previously (24), the source of COX-2 had been attributed to renal medullary interstitial cells, an unusual cell lineage of uncertain origin and function. Here, we provide genetic evidence that ICs of the CD are an important source of COX-2, which is induced by activation of $\mathrm{AT}_{1}$ receptors during hypertension. Although a previous study has reported little or no expression of COX-2 in CD epithelium (42), most of these experiments were carried out in normotensive, unperturbed animals. As in other tissues, expression of COX-2 in the kidney can be highly induced after various physiological stresses, and our studies show that such upregulation is induced in ICs by angiotensin II. This activation of COX-2 expression by angiotensin II in medullary $\mathrm{CD}$ contrasts with renal cortex, where $\mathrm{AT}_{1}$ receptors suppress expression of COX-2 as part of the shortloop feedback pathway for renin release. (43), perhaps suggesting distinct signals linking $\mathrm{AT}_{1}$ receptors and COX-2 in these two cell lineages.

Historically, the primary role of the IC was presumed to be regulation of acid-base balance. However, in recent years, it has become apparent that the IC participates in regulating extracellular fluid volume and plasma potassium levels through expression of a unique repertoire of transporters (4) and through paracrine communication with the PCs (5). For example, in the kidney, the anion exchanger pendrin is expressed predominantly in ICs and modulation of pendrin by $\mathrm{AT}_{1}$ receptors contributes to the pathogenesis of hypertension (17). Moreover, $\mathrm{PGE}_{2}$ generated in ICs regulate $\mathrm{ENaC}$ expression and thereby sodium balance in PCs during renal tubular acidosis (5). With ischemic kidney injury, ICs are among the first cell populations to express neutrophil gelatinase-associated lipocalin (NGAL), a marker of renal epithelial injury (44), perhaps indicating a role for these cells in sensing stress. Our studies assign an unexpected function to the IC as a source of mediators with a powerful capacity to modify responses to hypertension. As discussed above, these prostanoid mediators may act in a paracrine fashion to influence blood flow to the renal medulla or to directly modulate sodium reabsorption by the surrounding epithelium.

Our previous studies using kidney cross-transplants have highlighted the essential role of $\mathrm{AT}_{1}$ receptors within the kidney for blood pressure regulation (11) and angiotensin II-dependent hypertension (10), consistent with Guyton's hypothesis (45). As we have discussed, direct actions of $\mathrm{AT}_{1}$ receptors inside the kidney may affect fluid and solute excretion by controlling renal epithelial function and modulating renal blood flow and thereby influencing tubular fluid reabsorption. While the actions of $\mathrm{AT}_{1}$ receptors typically increase blood pressure, we describe here what we believe to be a novel pathway linked to $\mathrm{AT}_{1}$ receptors in the renal CD opposing the development of hypertension. This observation demonstrates unexpected complexity of the renal epithelial actions of angiotensin II. Furthermore, understanding the mechanisms of this pathway with powerful actions to resist the development of hypertension may have utility in optimizing antihypertensive treatments.

\section{Methods}

Experimental mice. Mice were bred and maintained in the Association for Assessment and Accreditation of Laboratory Animal Care-accredited animal facilities at the Durham Veterans' Affairs Medical Center (DVAMC) according to NIH guidelines. All the animal studies were approved by both the Duke University (IACUC no. A186-13-07) and DVAMC (IACUC no. 1506-002) Institutional Animal Care and Use Committees and conducted in accordance with the NIH Guide for the Care and Use of Laboratory Animals (National Academies Press, 2011). CDKO mice were generated as described previously (20). In brief, in order to delete the $\mathrm{AT}_{1 \mathrm{~A}}$ receptors from the $\mathrm{CD}$, we crossed an inbred $129 \mathrm{SvEv}$ transgenic mouse line expressing Cre recombinase specifically in the CD under the control of a Hoxb7 promoter (Hoxb7-Cre) with Agtr1allfl animals to

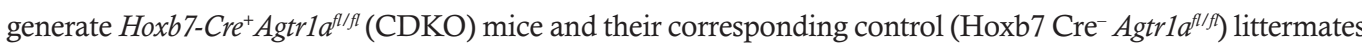
for experiments. Additionally, in order to delete the $\mathrm{AT}_{1 \mathrm{~A}}$ receptors only from PCs, we crossed an inbred 129/ SvEv transgenic mouse line expressing Cre recombinase under the control of an AQP2 promoter (AQP2-Cre) with $A g t r 1 a^{f l / f}$ mice as described previously (20). Global Agtr1a (AT1aKO) mice on a 129/SvEv background were generated as described previously (11). Membrane-targeted tdTomato (mT)/membrane-targeted EGFP 
$(m G)$ mice with loxP sites flanking the membrane-targeted dtTomato cassette followed by an N-terminal membrane-tagged version of EGFP were purchased from the Jackson Laboratory and crossed with the two Cre recombinase transgenic lines. $m T m G$ mice normally express red fluorescence protein in all tissues. When $C r e$ is present, the $m T$ cassette is deleted, triggering expression of $m G(46)$.

Intra-arterial blood pressure measurement by radiotelemetry. Blood pressures were measured in conscious, unrestrained mice after the implantation of a pressure-sensing catheter (TA11PA-C10, Transoma Medical) via the left common carotid artery as described previously (21). In separate experiments, baseline blood pressures were measured on 5 consecutive days while the animals ingested a conventional diet containing $0.4 \%$ sodium chloride. After baseline blood pressure levels were measured, mice were placed on a low-salt diet $(<0.002 \% \mathrm{NaCl})$ for 5 days and then on a high-salt $(6 \% \mathrm{NaCl})$ diet (Harlan Teklad) for another 5 days while blood pressures were continuously monitored.

Angiotensin II-induced hypertension and administration of L-NAME or rofecoxib. Baseline blood pressure was recorded for 3 consecutive days, and then an osmotic minipump (Alzet model 2004, DURECT) infusing angiotensin II (Sigma Aldrich) at a rate of $1,000 \mathrm{ng} / \mathrm{kg}$ per minute was implanted subcutaneously, as described previously (10). In separate groups of experiments, 1 week after beginning of angiotensin II infusion, we added either L-NAME $(20 \mathrm{mg} / \mathrm{kg} / \mathrm{d})$ to the drinking water or rofecoxib $(10 \mathrm{mg} / \mathrm{kg} / \mathrm{d}$; Sequoia Research) to the chow, and blood pressure measurements continued for another week.

Sodium balance studies. Measurements of sodium balance were carried out daily prior to and during chronic angiotensin II infusion with individual metabolic cages and a gel diet containing nutrients, water, and $0.1 \% \mathrm{w} / \mathrm{w}$ sodium (Nutra-Gel; Bio-Serv) as described previously (21).

Measurement of urinary nitrite and nitrate levels. Urinary nitrite and nitrate levels were measured daily prior to and during chronic angiotensin II infusion using an ELISA kit (Cayman Chemical, no. 780001) per the manufacturer's instructions (47). Urinary creatinine levels were assessed using an alkaline picrate assay (Creatinine Companion, Exocell Inc.).

Quantification of COX-2 mRNA levels in the kidney. Renal cortex and inner medulla were microscopically dissected, and total RNA was isolated by using an RNeasy Mini Kit according to the manufacturer's instructions. COX-2 and 18S expression levels were determined using TaqMan primers (Applied Biosyste$\mathrm{ms}$ ) by real-time PCR, as described previously (48).

Immunofluorescence staining. Kidneys were fixed in 4\% paraformaldehyde and incubated in $30 \%$ sucrose overnight. 5- $\mu \mathrm{m}$ longitudinal cryostat sections of kidney from CDKO and control mice were hydrated through graded ethanol solutions (100\%-50\%), equilibrated to water, and subjected to microwave antigen retrieval as described previously (20). For COX-2 staining, kidneys were fixed with GPAS (2.5\% glutaraldehyde, $10 \mathrm{mM}$ sodium m-periodate, $40 \mathrm{mM}$ phosphate buffer, and 1\% acetic acid) as described in ref. 49. Sections were blocked with 5\% skim milk in PBS, $0.1 \%$ Triton X-100 for 60 minutes and incubated with a polyclonal rabbit anti-GFP antibody (1:1,000, Invitrogen), polyclonal goat anti-AQP2 antibody (1:500; C-17; Santa Cruz Biotechnology Inc.), polyclonal rabbit anti-V-ATPase (1:500; H-140; Santa Cruz Biotechnology Inc.), polyclonal goat anti-V-ATPase (1:500, N-20; Santa Cruz Biotechnology Inc.), or polyclonal goat anti-COX-2 antibody (1:500; M-19; Santa Cruz Biotechnology Inc.) diluted in 5\% skim milk in PBS overnight at $4^{\circ} \mathrm{C}$. Adjacent sections were washed extensively in $1 \times$ PBS and subsequently incubated with Alexa Fluor 568 and Alexa Fluor 568 as secondary antibodies $(1: 1,000)$ (Invitrogen) for 1 hour at room temperature. After being washed in PBS, the sections were mounted using Fluoromount-G (SouthernBiotech) containing $2 \mu \mathrm{g} / \mathrm{ml}$ DAPI (Sigma-Aldrich). Confocal fluorescence images were taken using a confocal Zeiss LSM 510 microscope and analyzed with AxioVision LE software (Carl Zeiss MicroImaging Solutions $\mathrm{GmbH})$.

Immunoblotting for COX-2 expression levels in IMCD suspensions. Suspensions enriched for CD segments from control, $\mathrm{CDKO}, \mathrm{PCKO}$, and global $\mathrm{AT}_{1 \mathrm{~A}} \mathrm{KO}$ mice were prepared as described previously (25) with slight modifications. Inner medullas were dissected from kidneys of 3 mice and then incubated in an enzymatic solution containing collagenase, hyaluronidase, and DNAse at $37^{\circ} \mathrm{C}$ for 40 minutes at 650 $\mathrm{mOsm} / \mathrm{kg}$ with urea $/ \mathrm{NaCl}$ to approximate the osmolality of the inner medulla. The suspension was passed through $100 \mu \mathrm{m}$ mesh, followed by 3 rinses, pelleting at $60 \mathrm{~g}$, and resuspending tubules in fresh buffer. A photomicrograph of a typical IMCD suspension is shown in Supplemental Figure 6. To test the purity of these suspensions, we carried out Western blot analysis for markers specific for distinct cell compartments in the kidney: (a) aquaporin-2 (AQP2) for CD, (b) NKCC2 for medullary thick ascending limb of the loop of Henle (mTAL), and (c) smooth muscle $\alpha$-actin (sm $\alpha$-actin) for vascular structures 
such as vasa recta. For these studies IMCD suspensions were homogenized and total protein was measured by the Bradford method. Equal amounts of protein $(5 \mu \mathrm{g})$ were loaded onto a polyacrylamide gel, and proteins were resolved by electrophoresis. Target proteins were identified using specific antibodies, and levels of expression were quantified by Western blotting followed by densitometric analysis. As shown in Supplemental Figure 7, A-C, these preparations were highly enriched for IMCD markers without evidence for significant contamination by mTAL or vascular structures. For COX-2 expression, IMCD suspensions are homogenized in a buffer containing 20 mM HEPES (pH 7.4), 2 mM EDTA, 300 $\mathrm{mM}$ sucrose, $1.0 \%$ IGEPAL, $0.1 \%$ SDS, and a 1:100 dilution of a protease inhibitor cocktail (Sigma Aldrich) The membrane was incubated in blocking buffer containing $20 \mathrm{mmol} / 1$ Tris, $137 \mathrm{mmol} / 1 \mathrm{NaCl}$, $5 \%$ nonfat dry milk, and $0.1 \%$ Tween 20 for 30 minutes and then with a 1:2,000 dilution of a COX-2specific antibody (Santa Cruz Biotechnology Inc., 1747) in blocking buffer overnight at $4^{\circ} \mathrm{C}$. After washing, the membrane was incubated with a secondary antibody (dilution 1:3,000) against the appropriate IgG conjugated to horseradish peroxidase (Amersham Biosciences). The reaction products were detected by enhanced chemiluminescence. To control for loading, detection of GAPDH was conducted using a 1:20,000 dilution of a monoclonal antibody (Millipore MAB374). Bands were semiquantified by densitometry, and the data are expressed as percent change in COX-2/GAPDH.

Immunoblotting for renal COX-2 expression levels. For assessment of renal medullary COX-2 expression levels after chronic angiotensin II treatment, renal inner medulla was dissected and placed into 30 $\mathrm{mM}$ Tris- $\mathrm{HCl}(\mathrm{pH} 8.0)$ with $100 \mu \mathrm{M}$ PMSF adapted from previous studies (50). After centrifugation at $10,000 \mathrm{~g}$ for 10 minutes, the supernatant was centrifuged for 60 minutes at $110,000 \mathrm{~g}$ to prepare microsomes. The microsomal pellet was solubulized in $50 \mathrm{mM}$ Tris- $\mathrm{HCl}, 150 \mathrm{mM}$ sodium chloride, $2 \mathrm{mM}$ EDTA, $0.2 \%$ SDS, and $0.2 \%$ Triton X-100 ( $\mathrm{pH} 7.4$ ). A total of $15 \mu \mathrm{g}$ of total protein was loaded onto $12 \%$ SDS-PAGE gels and then transferred to nitrocellulose membranes according to the manufacturer's instructions (X-Cell Blot Module, Invitrogen). Membranes were blocked in blocking buffer (5\% nonfat dry milk and $0.1 \%$ Tween 20 in PBS) for 1 hour at room temperature and then incubated with primary rabbit polyclonal anti-COX-2 antibody (1:2,000; batch 160126, Cayman Chemical) and mouse anti- $\beta$ actin $(1: 10,000)$ (Sigma-Aldrich, A5316) overnight at $4^{\circ} \mathrm{C}$. Bound primary antibody was detected with either anti-rabbit or anti-mouse HRP-conjugated secondary antibodies (1:2000) (Bio-Rad). Proteins were detected by enhanced chemiluminescence according to the manufacturer's directions (GE HealthCare). For densitometric quantification of COX-2 proteins, the immunoblots were converted into a digital format and analyzed using ImageJ (NIH). All densitometric values were normalized to an actin loading control. Immunoblots from each tissue sample were performed in triplicate.

Urinary excretion of prostanoid metabolites. Urinary excretion of prostanoids were measured as described previously (51). In brief, 24-hour urine samples were collected by metabolic cage at baseline and after 2 weeks of angiotensin II infusion. To remove particulate matter, urine samples were centrifuged and then immediately aliquoted and frozen at $-80^{\circ} \mathrm{C}$ until assay. Stable urinary prostanoid metabolites (13,14-dihydro-15-keto-PGE ${ }_{1} / \mathrm{PGE}_{2}$ [prostaglandin $\mathrm{E}_{2}$ ], thromboxane $\mathrm{TxB}_{2}\left[\mathrm{TxA}_{2}\right.$ ], and 6-keto-PGF [prostaglandin $\mathrm{I}_{2}$ ]) were measured using specific competitive enzyme immunoassays (Cayman Chemical, nos. 514010, 501020, 515211). Creatinine levels in urine were assessed using an alkaline picrate assay (Creatinine Companion, Exocell Inc.).

Cell culture experiments in MDCK C-11 cells. MDCK C-11 cells, a gift from Hans Oberleithner (Institute of Physiology II, University of Münster, Münster, Germany), were grown in Earle's medium supplemented with FCS, $100 \mathrm{U} / \mathrm{ml}$ penicillin, and $100 \mu \mathrm{g} / \mathrm{ml}$ streptomycin (Biochrom). AT receptor-expressing MDCK $\mathrm{C}-11$ cells were generated by retroviral transduction. The GFP-tagged $\mathrm{AT}_{1}$ receptor was kindly provided by László Hunyady (Semmelweis University, Budapest, Hungary). The AT 1 receptor was cloned into the pLEGFP-C1 vector HindIII/NotI via PCR with the following primers: 5'-CGCGGGAAGCTTATGGCCCTTAACTCTTC and 5'-GCGGGGGCGGCCGCCTCACTCCACCTCAAAAC. Briefly, infectious viral supernatants - containing the sequence verified $\mathrm{AT}_{1}$ receptor $\mathrm{CDNA}$ or the GFP control - were produced by transient transfection of HEK293T cells. MDCK C-11 cells were infected with viral supernatants containing either the $\mathrm{AT}_{1}$ receptor or a GFP control for 48 hours. Selection of transduced cells was performed by G418 (800 $\mu \mathrm{g} / \mathrm{ml})$. After selection, the maintenance dose of G418 was $400 \mu \mathrm{g} / \mathrm{ml}$. AT ${ }_{1}$ receptor expression was confirmed by quantitative real-time PCR (qPCR), and activation of the $\mathrm{AT}_{1}$ receptor signaling pathway p42/44 by angiotensin II was confirmed by Western blot analysis (data not shown). After 6 hours of angiotensin II $(0.1 \mu \mathrm{M})$ stimulation, MDCK C-11 cells were lysed with heated Laemmli buffer and 
centrifuged $\left(20000 \mathrm{~g}, 30\right.$ minutes, $\left.4^{\circ} \mathrm{C}\right)$. Equal amounts of protein were loaded onto $10 \%$ SDS-PAGE gels and then transferred to nitrocellulose membranes according to manufacturer's instructions (X-Cell Blot Module, Invitrogen). Membranes were blocked and incubated with primary rabbit polyclonal anti-COX-2 antibody (1:2,000; batch 160126) Cayman Chemical) and mouse anti- $\beta$-actin $(1: 20,000)$ (Sigma-Aldrich, A5316) overnight at $4^{\circ} \mathrm{C}$ as described above.

For measurement of the prostaglandin $\mathrm{E}_{2}$ secretion rate, the supernatants from angiotensin II-stimulated $(0.1 \mu \mathrm{M})$ MDCK C-11 cells were collected and measured with a commercially available competitive enzyme immunoassay (Cayman Chemical) as described above.

Statistics. The values for each parameter within a group are expressed as mean \pm SEM. All data were analyzed by either 1- or 2-way ANOVA, followed by Bonferroni's multiple comparison post-hoc test, Student's $t$ test, or Mann-Whitney $U$ test after testing for normal distribution. $P$ values less than 0.05 were considered significant.

\section{Author contributions}

JS, SBG, and TMC designed the research; JS, DC, MH, MAS, TY, EK, and SBG performed the research; JS, DC, MH, MAS, TY, and EK analyzed the data; and JS and TMC wrote the manuscript.

\section{Acknowledgments}

These studies were supported by NIH grant R01DK105049, the Medical Research Service of the Department of the Veterans Affairs Administration, the Edna and Fred L. Mandel Center for Hypertension and Atherosclerosis Research, the Duke O'Brien Center for Kidney Research, the German Research Society (STE2042/1-1), and a fellowship grant of the German Hypertension Society. The authors acknowledge the contributions of Tim Oliver (deceased), Department of Cell Biology, Duke University Medical Center, for his methodical assistance.

Address correspondence to: Thomas M. Coffman, MSRB2 Room 2018, Duke University Medical Center, 2 Genome Court, Durham, North Carolina 27710, USA. Phone: 919.684.9788; E-mail: t.coffman@duke.edu.

1. Lifton RP, Gharavi AG, Geller DS. Molecular mechanisms of human hypertension. Cell. 2001;104(4):545-556.

2. Levine DZ, Iacovitti M, Buckman S, Hincke MT, Luck B, Fryer JN. ANG II-dependent HCO3- reabsorption in surviving rat distal tubules: expression/activation of H(+)-ATPase. Am J Physiol. 1997;272(6 Pt 2):F799-F808.

3. Brown D, Wagner CA. Molecular mechanisms of acid-base sensing by the kidney. J Am Soc Nephrol. 2012;23(5):774-780.

4. Eladari D, Chambrey R, Peti-Peterdi J. A new look at electrolyte transport in the distal tubule. Annu Rev Physiol. 2012;74:325-349.

5. Gueutin V, et al. Renal $\beta$-intercalated cells maintain body fluid and electrolyte balance. J Clin Invest. 2013;123(10):4219-4231.

6. Ge Y, Huang Y, Kohan DE. Role of the renin-angiotensin-aldosterone system in collecting duct-derived endothelin-1 regulation of blood pressure. Can J Physiol Pharmacol. 2008;86(6):329-336.

7. Gumz ML, et al. The circadian clock protein Period 1 regulates expression of the renal epithelial sodium channel in mice. $J$ Clin Invest. 2009;119(8):2423-2434.

8. Ito M, et al. Regulation of blood pressure by the type 1A angiotensin II receptor gene. Proc Natl Acad Sci USA. 1995;92(8):3521-3525

9. ONTARGET Investigators, et al. Telmisartan, ramipril, or both in patients at high risk for vascular events. $N E n g l J M e d$. 2008;358(15):1547-1559.

10. Crowley SD, et al. Angiotensin II causes hypertension and cardiac hypertrophy through its receptors in the kidney. Proc Natl Acad Sci USA. 2006;103(47):17985-17990.

11. Crowley SD, et al. Distinct roles for the kidney and systemic tissues in blood pressure regulation by the renin-angiotensin system. J Clin Invest. 2005;115(4):1092-1099.

12. Bouby N, Hus-Citharel A, Marchetti J, Bankir L, Corvol P, Llorens-Cortes C. Expression of type 1 angiotensin II receptor subtypes and angiotensin II-induced calcium mobilization along the rat nephron. J Am Soc Nephrol. 1997;8(11):1658-1667.

13. Burns KD, Regnier L, Roczniak A, Hébert RL. Immortalized rabbit cortical collecting duct cells express AT1 angiotensin II receptors. Am J Physiol. 1996;271(6 Pt 2):F1147-F1157.

14. Peti-Peterdi J, Warnock DG, Bell PD. Angiotensin II directly stimulates ENaC activity in the cortical collecting duct via AT(1) receptors. J Am Soc Nephrol. 2002;13(5):1131-1135.

15. Mamenko M, Zaika O, Ilatovskaya DV, Staruschenko A, Pochynyuk O. Angiotensin II increases activity of the epithelial Na+ channel (ENaC) in distal nephron additively to aldosterone. J Biol Chem. 2012;287(1):660-671.

16. Chen D, et al. Impact of angiotensin type 1A receptors in principal cells of the collecting duct on blood pressure and hypertension. Hypertension. 2016;67(6):1291-1297.

17. Verlander JW, et al. Angiotensin II acts through the angiotensin 1a receptor to upregulate pendrin. Am J Physiol Renal Physiol. 2011;301(6):F1314-F1325.

18. Pech V, Zheng W, Pham TD, Verlander JW, Wall SM. Angiotensin II activates H+-ATPase in type A intercalated cells. $J A m$ Soc Nephrol. 2008;19(1):84-91. 
19. Wagner CA, et al. Angiotensin II stimulates $\mathrm{H}+$-ATPase activity in intercalated cells from isolated mouse connecting tubules and cortical collecting ducts. Cell Physiol Biochem. 2011;28(3):513-520.

20. Stegbauer J, et al. AT1 receptors in the collecting duct directly modulate the concentration of urine. J Am Soc Nephrol. 2011;22(12):2237-2246.

21. Gurley SB, et al. AT1A angiotensin receptors in the renal proximal tubule regulate blood pressure. Cell Metab. 2011;13(4):469-475.

22. Dickhout JG, Mori T, Cowley AW. Tubulovascular nitric oxide crosstalk: buffering of angiotensin II-induced medullary vasoconstriction. Circ Res. 2002;91(6):487-493.

23. Schneider MP, Ge Y, Pollock DM, Pollock JS, Kohan DE. Collecting duct-derived endothelin regulates arterial pressure and Na excretion via nitric oxide. Hypertension. 2008;51(6):1605-1610.

24. Qi Z, et al. Opposite effects of cyclooxygenase-1 and -2 activity on the pressor response to angiotensin II. J Clin Invest. 2002;110(1):61-69.

25. Chou CL, et al. Regulation of aquaporin-2 trafficking by vasopressin in the renal collecting duct. Roles of ryanodine-sensitive Ca2+ stores and calmodulin. J Biol Chem. 2000;275(47):36839-36846.

26. Herrera M, Garvin JL. Angiotensin II stimulates thick ascending limb NO production via AT(2) receptors and Akt1-dependent nitric-oxide synthase 3 (NOS3) activation. J Biol Chem. 2010;285(20):14932-14940.

27. Gekle M, Wünsch S, Oberleithner H, Silbernagl S. Characterization of two MDCK-cell subtypes as a model system to study principal cell and intercalated cell properties. Pflugers Arch. 1994;428(2):157-162.

28. Navar LG, Harrison-Bernard LM, Wang CT, Cervenka L, Mitchell KD. Concentrations and actions of intraluminal angiotensin II. J Am Soc Nephrol. 1999;10 Suppl 11:S189-S195.

29. Sun P, Yue P, Wang WH. Angiotensin II stimulates epithelial sodium channels in the cortical collecting duct of the rat kidney. Am J Physiol Renal Physiol. 2012;302(6):F679-F687.

30. Pech V, Kim YH, Weinstein AM, Everett LA, Pham TD, Wall SM. Angiotensin II increases chloride absorption in the cortical collecting duct in mice through a pendrin-dependent mechanism. Am J Physiol Renal Physiol. 2007;292(3):F914-F920.

31. Wei Y, Wang W. Angiotensin II stimulates basolateral K channels in rat cortical collecting ducts. Am J Physiol Renal Physiol. 2003;284(1):F175-F181.

32. San-Cristobal P, et al. Angiotensin II signaling increases activity of the renal Na-Cl cotransporter through a WNK4-SPAK-dependent pathway. Proc Natl Acad Sci USA. 2009;106(11):4384-4389.

33. Solomon DH, Schneeweiss S, Levin R, Avorn J. Relationship between COX-2 specific inhibitors and hypertension. Hypertension 2004;44(2):140-145

34. Hu SS, Bradshaw HB, Chen JS, Tan B, Walker JM. Prostaglandin E2 glycerol ester, an endogenous COX-2 metabolite of 2-arachidonoylglycerol, induces hyperalgesia and modulates NFkappaB activity. Br J Pharmacol. 2008;153(7):1538-1549.

35. Yang T, et al. Regulation of cyclooxygenase expression in the kidney by dietary salt intake. Am J Physiol. 1998;274(3 Pt 2):F481-F489.

36. Zewde T, Mattson DL. Inhibition of cyclooxygenase-2 in the rat renal medulla leads to sodium-sensitive hypertension. Hypertension. 2004;44(4):424-428.

37. Mattson DL. Importance of the renal medullary circulation in the control of sodium excretion and blood pressure. Am JPhysiol Regul Integr Comp Physiol. 2003;284(1):R13-R27.

38. Mattson DL, Roman RJ, Cowley AW. Role of nitric oxide in renal papillary blood flow and sodium excretion. Hypertension. 1992;19(6 Pt 2):766-769.

39. Sparks MA, et al. Vascular Type 1A Angiotensin II Receptors Control BP by Regulating Renal Blood Flow and Urinary Sodium Excretion. J Am Soc Nephrol. 2015;26(12):2953-2962.

40. Breyer MD, Breyer RM. Prostaglandin receptors: their role in regulating renal function. Curr Opin Nephrol Hypertens. 2000;9(1):23-29.

41. Zhang MZ, et al. Inhibition of cyclooxygenase-2 in hematopoietic cells results in salt-sensitive hypertension. J Clin Invest. 2015;125(11):4281-4294.

42. Câmpean V, Theilig F, Paliege A, Breyer M, Bachmann S. Key enzymes for renal prostaglandin synthesis: site-specific expression in rodent kidney (rat, mouse). Am J Physiol Renal Physiol. 2003;285(1):F19-F32.

43. Zhang MZ, Yao B, Cheng HF, Wang SW, Inagami T, Harris RC. Renal cortical cyclooxygenase 2 expression is differentially regulated by angiotensin II AT(1) and AT(2) receptors. Proc Natl Acad Sci USA. 2006;103(43):16045-16050.

44. Paragas N, et al. The Ngal reporter mouse detects the response of the kidney to injury in real time. Nat Med. $2011 ; 17(2): 216-222$.

45. Guyton AC. Blood pressure control — special role of the kidneys and body fluids. Science. 1991;252(5014):1813-1816.

46. Muzumdar MD, Tasic B, Miyamichi K, Li L, Luo L. A global double-fluorescent Cre reporter mouse. Genesis. 2007;45(9):593-605.

47. Crowley SD, Song YS, Lin EE, Griffiths R, Kim HS, Ruiz P. Lymphocyte responses exacerbate angiotensin II-dependent hypertension. Am J Physiol Regul Integr Comp Physiol. 2010;298(4):R1089-R1097.

48. Zhang JD, et al. A novel role for type 1 angiotensin receptors on $\mathrm{T}$ lymphocytes to limit target organ damage in hypertension. Circ Res. 2012;110(12):1604-1617.

49. Zhang MZ, Su Y, Yao B, Zheng W, Decaestecker M, Harris RC. Assessing the application of tissue microarray technology to kidney research. J Histochem Cytochem. 2010;58(5):413-420.

50. Wang L, Flannery PJ, Rosenberg PB, Fields TA, Spurney RF. Gq-dependent signaling upregulates COX2 in glomerular podocytes. J Am Soc Nephrol. 2008;19(11):2108-2118.

51. Facemire CS, Griffiths R, Audoly LP, Koller BH, Coffman TM. The impact of microsomal prostaglandin e synthase 1 on blood pressure is determined by genetic background. Hypertension. 2010;55(2):531-538. 